\title{
Effect of Cold Joint on Stratified Slabs
}

\author{
${ }^{1}$ Tarek Aly, ${ }^{2}$ Sameh Yehia*, ${ }^{3}$ Ahmed Mohamed Abd Elkhalek, ${ }^{4}$ Osama Hassaan \\ ${ }^{1}$ Professor, Faculty of Engineering, Helwan University, Egypt \\ ${ }^{2}$ Associate Professor, Faculty of Engineering, Suez University, Egypt \\ ${ }^{3}$ Assistant Professor, Faculty of Engineering Helwan University, Egypt \\ ${ }^{4}$ Higher Institute of Engineering, Shorouk Academy, Egypt
}

\begin{abstract}
Stratified Slab consist of two or more types of concrete; in particular, of composite materials consisting of High Strength Concrete (HSC) and Normal Strength Concrete (NSC). This study had the effect of delay time overlap between two concrete mixes (15 minutes and 60 minutes). An experimental program was conducted to investigate the flexural behavior of two HSC/NSC slabs that had subjected to double static loads. The most important achievement conclusion is the success of the idea of casting different strengths concrete layers using a short time (60 minutes) interval to improve the flexural behavior of the slab.
\end{abstract}

Keywords- Composite Slab, Multi-Layers Concrete, High Strength Concrete, Effect of Cold Joint.

\section{INTRODUCTION}

The usage of HSC has been risen in the past decades, to enhance structural element and retain the volume of structural elements. The usage of the NSC may lead to larger volumes of concrete, which results miss leading in the cost of structure. On the other hand, the usage of only HSC may lead to over estimated cost to an ordinary structure. As a result, the concept of using NSC with HSC or any advanced concrete to obtain the benefits of two materials is developed.

The lower layer was cast by NSC $(25 \mathrm{MPa})$ to reduce the cost, but the upper layer of compression zone was cast by HSC $(60 \mathrm{MPa})$ to enhance the behavior of concrete slabs in both flexural and deformation. A lot of studies had the impact of the time delay when casting the second layer of concrete on its mechanical properties [1], [2], [3], [4], [5], [6]. Their results indicated that when cast the second layer of concrete at early age (about 1 hour), the compressive, flexural, and split tensile strengths decreased by neglected ratios. so, this study will show the flexural behavior for composite sections (HSC/NSC) by taking short time lap (15minutes and 60minutes) between casting the two layers. The two times was chosen to study which of them satisfy the good bond between the two layers.

\section{EXPERIMENTAL PROGRAM}

HSC mix proportion was done according to previous studies, [7], [8]. Trial mix was placed and was tested to ensure required strength. The used concrete mixes were designed to develop a cubic compressive strength of $25 \mathrm{MPa}$ for NSC and $60 \mathrm{MPa}$ for HSC. The concrete mix for the test specimen was made from available materials, which were consists of cement content, crushed dolomite, natural sand, silica fume, superplasticizer, and tap drinking water.
Concrete ingredients were tested according to the Egyptian Standard Specifications, [9]. The cement used in this research was CEMI $42.5 \mathrm{~N}$ produced by the Suez Cement Company Suez factory, [10]. Aggregate was tested according to ESS $1109 / 2002$ [11]. Silica fume is commercially available through construction chemical company. (Visocrete-3425) high performance superplasticizer was used for the product HSC in order to achieve its required workability [12]. The steel reinforcement was a high-grade steel B400B-R bars of diameters $12 \mathrm{~mm}$ and $16 \mathrm{~mm}$, [13]. Table 1 to Table 5 show properties of used materials.

Two mixes were used to cast slabs (NSC 25MPa \& HSC $60 \mathrm{MPa}$ ) and they were designed for target 28 days' compressive strength of $25 \mathrm{MPa}$ and $60 \mathrm{MPa}$ respectively. Table 6 show the mix proportions of the two used concrete mixes.

Table (1) Physical Mechanical and Properties of the Used Cement (CEM I $42.5 \mathrm{~N})$

\begin{tabular}{|c|c|c|c|}
\hline \multicolumn{2}{|c|}{ Physical Properties } & $\begin{array}{l}\text { Measured } \\
\text { Values }\end{array}$ & $\begin{array}{c}\text { Limits of the E.S.S } \\
4756-1 / 2013,[10]\end{array}$ \\
\hline \multicolumn{2}{|c|}{ Fineness $\left(\mathrm{cm}^{2} / \mathrm{gm}\right)$} & 3630 & - \\
\hline \multicolumn{2}{|c|}{ Specific Gravity } & 3.15 & - \\
\hline \multicolumn{2}{|c|}{ Expansion (mm) } & 1.0 & Not more than 10 \\
\hline \multicolumn{2}{|c|}{$\begin{array}{c}\text { Initial Setting Time } \\
\text { (minutes) }\end{array}$} & 120 & Not less than 60 min \\
\hline \multicolumn{2}{|c|}{$\begin{array}{c}\text { Final Setting Time } \\
\text { (minutes) }\end{array}$} & 180 & - \\
\hline \multirow{2}{*}{$\begin{array}{c}\text { Compressive } \\
\text { Strength } \\
\left(\mathbf{N} / \mathbf{m m}^{2}\right)\end{array}$} & $\begin{array}{c}2 \\
\text { day } \\
\text { s }\end{array}$ & 20.1 & Not less than 10 \\
\hline & $\begin{array}{c}28 \\
\text { day } \\
\text { S }\end{array}$ & 52.54 & $\begin{array}{c}\text { Not less than } 42.5 \text { and } \\
\text { not more than } 62.5\end{array}$ \\
\hline
\end{tabular}

TAble (2) Physical And Mechanical Properties of NAtural CoARse AGGREGATE.

\begin{tabular}{|c|c|c|}
\hline Property & Results & $\begin{array}{c}\text { Limits of ESS } \\
\mathbf{1 1 0 9 / 2 0 0 2},[11]\end{array}$ \\
\hline Specific Weight & 2.55 & - \\
\hline Bulk Density $\left(\mathbf{t} / \mathbf{m}^{\mathbf{3}}\right)$ & 1.6 & - \\
\hline Water absorption\% & 1.67 & Not more than 2.5 \\
\hline Clay and Fine Dust Content\% & 1.6 & Not more than 2.5 \\
\hline Flakiness Index\% & 36.8 & Not more than $40 \%$ \\
\hline Elongation Index\% & 9.6 & Not more than 2.5 \\
\hline Abrasion Index\% & 17.8 & Not more than $30 \%$ \\
\hline Impact Value \% & 12.60 & Not more than $45 \%$ \\
\hline
\end{tabular}


TABle (3) Physical Properties of Fine Aggregate. Properties

\begin{tabular}{|c|c|c|}
\hline Properties & Results & Limits* \\
\hline Specific gravity & 2.61 & - \\
\hline Bulk density (t/m3) & 1.78 & - \\
\hline $\begin{array}{c}\text { Materials finer than no 200 } \\
\text { sieve\% }\end{array}$ & 2.7 & Less than $4 \%$ \\
\hline
\end{tabular}

* The limits according to Egyptian code of practice 207/2007.

TABle (4) Physical Properties of the Silica FuME.

$$
\text { Properties }
$$

Specific surface area $\left(\mathrm{cm}^{2} / \mathrm{gm}\right)$

Particle size $(\mu \mathrm{m})$

Bulk density $\left(\mathrm{kg} / \mathrm{m}^{3}\right)$ Specific gravity

$$
\text { Color }
$$

* By the provider data sheet

\begin{tabular}{|c|c|c|c|c|}
\hline \multirow[b]{2}{*}{ Properties } & \multicolumn{2}{|c|}{ Measured Values } & \multicolumn{2}{|c|}{$\begin{array}{c}\text { Minimum } \\
\text { Specification Limits* }\end{array}$} \\
\hline & $\begin{array}{c}\text { High Grad } \\
\text { Steel } \\
\text { B400B-R } \\
\Phi 12\end{array}$ & $\begin{array}{c}\text { High Grad } \\
\text { Steel } \\
\text { B400B-R } \\
\Phi 16\end{array}$ & $\Phi 12$ & $\Phi 16$ \\
\hline $\begin{array}{l}\text { Yield stress } \\
\left(\mathbf{N} / \mathbf{m m}^{2}\right)\end{array}$ & 430 & 463 & 400 & 400 \\
\hline $\begin{array}{l}\text { Ultimate stress } \\
\qquad\left(\mathrm{N} / \mathrm{mm}^{2}\right)\end{array}$ & 650 & 685 & 600 & 600 \\
\hline $\begin{array}{l}\text { Weight per meter } \\
\text { length }(\mathrm{Kg})\end{array}$ & 0.879 & 1.606 & 0.888 & 1.58 \\
\hline Rm/ReH & 1.25 & 1.26 & 1.08 & 1.08 \\
\hline Elongation \% & 12.0 & 13.0 & 5 & 5 \\
\hline
\end{tabular}

Table (5) Mechanical Properties of The Used High-Grade SteEl.

TABLE (6) SHOws the Mix IngRedients FOR CONCRETE MiXeS

\section{Ingredients}

Cement $\left(\mathrm{Kg} / \mathrm{m}^{3}\right)$

S.F $\left(\mathrm{Kg} / \mathrm{m}^{3}\right)$

Sand $\left(\mathrm{Kg} / \mathrm{m}^{3}\right)$

Coarse agg. $\left(\mathrm{Kg} / \mathrm{m}^{3}\right)$

Water $\left(\mathrm{Kg} / \mathrm{m}^{3}\right)$

Super Plasticizer \% of cement
Proportions

\begin{tabular}{|c|c|}
\hline NSC & HSC \\
\hline 360 & 550 \\
\hline- & 55 \\
\hline 627 & 480 \\
\hline 1363 & 895 \\
\hline 180 & 170 \\
\hline- & $1 \%$ \\
\hline
\end{tabular}

The NSC mix was mixed as usual for mixing the ordinary concrete mix in the testing laboratory. In contrast and due to the low water cement ratio (w/c) in the HSC mix, a special way of mixing the HSC mix was used using a van mixer. Firstly, the Fine materials which include Cement and silica fume were dry mixed together, then half the amount of mixing water was added gradually to the fines and mixing continues for two minutes. After that the superplasticizer was added to the remaining water then added them to the mix. Finally, fine aggregate was added gradually to the mix, followed by the coarse aggregate and were mixed continuously for 5 to 6 minutes till the desired workability was achieved.

Steel reinforcement cage was arranged and placed in its proper position in the forms. Plastic blocks with $2 \mathrm{~cm}$ height were used to keep the reinforcement in its proper position during casting. At the beginning the NSC concrete mix was placed in the forms according to the specific depth and compacted mechanically by internal electrical vibrator. Then
After 15 minutes the HSC mix was placed over the NSC mix layer for first slab S1 and after 60 minutes for the second slab.

The specimens were cured by spraying water at the morning and the afternoon for one week from casting and then the specimens were left in the ambient temperature until testing. Three concrete test cubes 150x150x150 mm were cast at the same time with the specimens to ensure exact achieved compressive strength. After the specimens were located under the cross head of the testing machine, five strain gauges for concrete type (PL-60-11) with length $6 \mathrm{~cm}$ were used to measure the compression strain of the concrete. In addition, deflection at mid-span of the slabs was measured by LVDT. Details of test specimens are tabulated in Table 7 and shown in Fig. 1

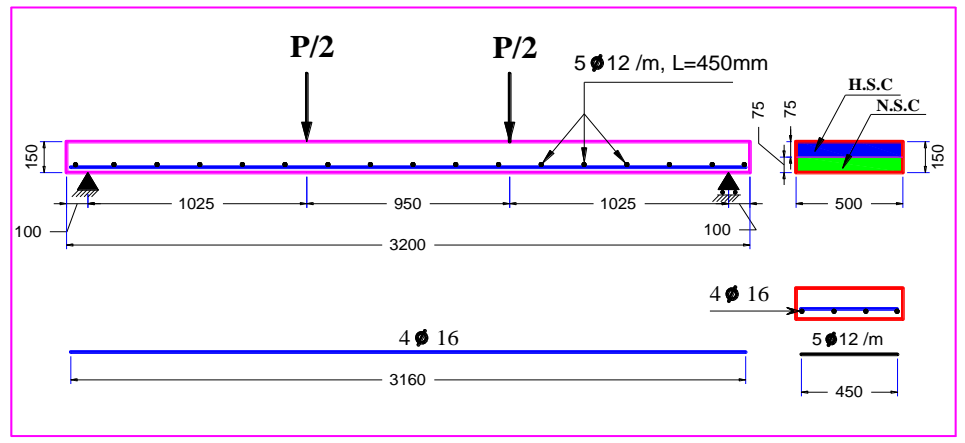

Fig. 1. Details of Specimens

TABle (7) Details of TeSt SPECIMENS

\begin{tabular}{|c|c|c|c|c|c|c|}
\hline Slab & $\begin{array}{c}\text { HSC } \\
\text { Thickness } \\
(\mathbf{m m})\end{array}$ & $\begin{array}{c}\text { NSC } \\
\text { Thickness } \\
(\mathbf{m m})\end{array}$ & $\begin{array}{c}\text { Time } \\
\text { Overlap } \\
\text { (minutes) }\end{array}$ & $\begin{array}{c}\text { Type of } \\
\text { concrete }\end{array}$ & $\begin{array}{c}\text { Main } \\
\text { RFT }\end{array}$ & $\begin{array}{c}\text { Secondary } \\
\text { RFT }\end{array}$ \\
\hline S1 & 75 & 75 & 15 & Stratified & $8 \Phi 16 / \mathrm{m}$ & $5 \Phi 12 / \mathrm{m}$ \\
\hline S2 & 75 & 75 & 60 & Stratified & $8 \Phi 16 / \mathrm{m}$ & $5 \Phi 12 / \mathrm{m}$ \\
\hline
\end{tabular}

\section{EXPERIMENTAL RESULTS}

The experimental results of tested slabs were summarized in Table (8) including the load at first crack (Pcr), load at first yielding of main steel (Py), ultimate experimental load $(\mathrm{Pu})$, deflection at mid span at yielding $(\Delta y)$, deflection at failure load $(\Delta \mathrm{f})$, the maximum strain of concrete at top surface $(\mathrm{Sc})$, the maximum strain of main reinforcement surface (Ss). The compressive strength for NSC and HSC cubes are 31.3 $\mathrm{MPa}$ and $63 \mathrm{MPa}$ respectively as an average of three tested cubes.

\begin{tabular}{|c|c|c|c|c|c|c|c|c|}
\hline Slab & $\begin{array}{c}\text { Pcr } \\
(\mathrm{KN})\end{array}$ & $\begin{array}{c}\mathbf{P y} \\
(\mathbf{K N})\end{array}$ & $\begin{array}{c}\mathbf{P u} \\
(\mathbf{K N})\end{array}$ & $\begin{array}{c}\text { Mu } \\
\text { (KN.M) }\end{array}$ & $\begin{array}{c}\Delta y \\
(\mathbf{m m})\end{array}$ & $\begin{array}{c}\Delta \mathbf{f} \\
(\mathbf{m m})\end{array}$ & $\begin{array}{c}\text { S c } \\
* 10^{-3}\end{array}$ & $\begin{array}{c}\text { Ss } \\
* 10^{-3}\end{array}$ \\
\hline S1 & 4.32 & 57.6 & 70.15 & 35.95 & 20.06 & 63 & 2.07 & 16.36 \\
\hline S2 & 7.22 & 78.66 & 94.91 & 48.64 & 27.37 & 73.4 & 1.97 & 11.17 \\
\hline
\end{tabular}

TABle (8) SumMARY OF EXPERIMENTAL RESUltS OF TEST SLABS SPECIMEN.

For S1, the load is constant after it reached the ultimate value but the deflection still increasing until the slab was crushed in compression zone at mid span of the slab. With regard to slab S2, the crushing had happened at the HSC part so this indicate the full bond between the two layers. Also, it is noted that, the ultimate load for slab S1 was lower than the 
ultimate load for slab S2, so this may be the two mixes were partially mixed within damping method.

Fig. 2, shows the load deflection relationship of the two slabs. The ultimate loads were 70.15 and $94.91 \mathrm{KN}$ for slabs $\mathrm{S} 1$ and $\mathrm{S} 2$ respectively. It was concluded that increasing the time overlap from 15 minutes in S1 to 60 minutes in S2, the ultimate load increase by $35.3 \%$. Also, the yielding load increased by $36.6 \%$ for $\mathrm{S} 2$ than $\mathrm{S} 1$. On the other hand, the slab $\mathrm{S} 1$ reached to the ultimate load $(70.15 \mathrm{KN})$ before the slab S2 reach the yielding load $(78.66 \mathrm{KN})$. So, this indicate the significant benefit for using the HSC in compression zone by using allowable time lap between casting the two layers.

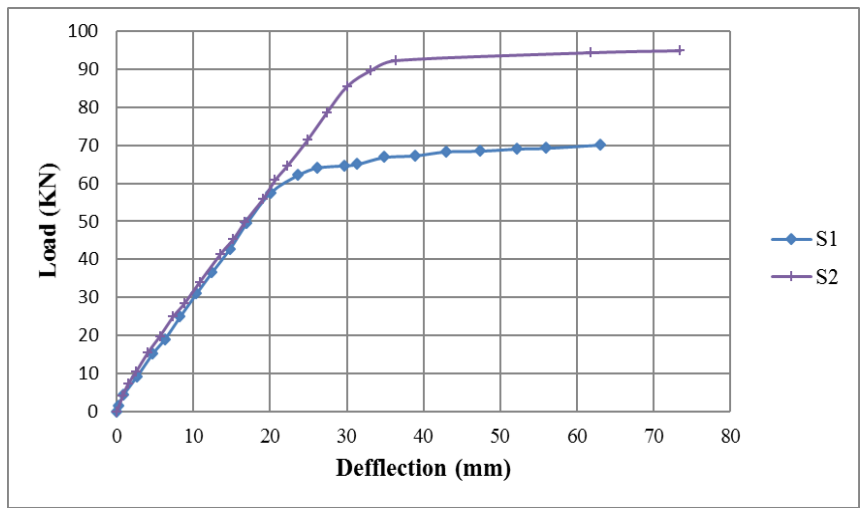

Fig. 2. Load-Deflection Relationship for different Slabs.

\section{CONCLUSIONS}

In this paper, an experimental study was carried out investigate the structural behavior of stratified slabs. Stratified "HSC/NSC" elements are appropriate for new constructions and conservation of existing structures. This research concerned on the new constructions by doing the layers at different short time lab between the layers to have good bond between them. From the experimental study, the following conclusions were observed:

1. Stratified slabs was loaded up to failure without sliding between the two layers, so this give more easily constructed method for stratified slabs.

2. At time overlap of 15 minutes, the two layers have partially mixed with them giving lower compressive strength at compression zone.

3. Increasing time overlap from 15 minutes for $\mathrm{S} 1$ to 60 minutes for $\mathrm{S} 2$, the ultimate load increased by $35.3 \%$. Also, the yielding load increased by $36.6 \%$ for S2 than $\mathrm{S} 1$.

4. The slab $\mathrm{S} 1$ reached to the ultimate load $(70.15 \mathrm{KN})$ before the slab S2 reach the yielding load $(78.66 \mathrm{KN})$ So, this indicate significant benefit for using the HSC at compression zone by using 60 minutes' time overlap between casting the two layers.

\section{REFERENCESS}

[1] Hanskat, Charles, S., "Shotcrete Placed in Multiple Layers does NOT Create Cold Joints," Concr. Int., vol. 36, no. 12, pp. 46-47, 2014.

[2] H. A. Mohamadien, N. Alle, and S. Ravindrarajah, "the Impact of the Time When Casting the Second Layer of Concrete on Its Mechanical Properties," vol. 41, no. 3, pp. 919-929, 2013.

[3] R. E. Miller, J. H. Ford, T. P. Dolen, B. K. Violetta, and L. D Olson, "Guide for Consolidation of Concrete Reported by $\mathrm{ACI}$ Committee 309," pp. 1-36.

[4] D. Beaupre, "Bond Strength of Shotcrete Repair," no. May, pp $12-15,1999$.

[5] V. R. Rathi and P. K. Kolase, "Effect of cold joint on strength of concrete," Int. J. Innov. Res. Sci. Eng. Technol., vol. 2, no. 9, pp. 4671-4679, 2013

[6] G. V Tapkire, "Time Laps and different joint affects Quality of Regular Concrete," vol. 3, no. 3, pp. 34-37, 2014.

[7] S. R. Hunchate, S. Chandupalle, V. G. Ghorpode, and V. R. T. C, "Mix Design of High Performance Concrete Using Silica Fume and Superplasticizer," vol. 3, no. 3, pp. 10735-10742, 2014.

[8] V. D. Sabale, M. D. Borgave, and S. D. Shinde, "Study the Effect of Addition of Silica Fume on Properties of High Strength Concrete," vol. 3, no. 1, pp. 267-270, 2014

[9] Egyptian Code of Practice for Design and Construction of Concrete Structures ECCS (203-2007). .

[10] "ES 4756-1 (2009) (Arabic): Cement Part:( 1) Composition, Specifications And Conformity Criteria For Common Cements," vol. 1, 2009.

[11] "ESS 1109/2002, Egyptian Standard Specification 'Aggregates for Concrete."”

[12] H. Performance and S. Concrete, "Sika ViscoCrete ${ }^{\circledR}-3425$," no. 12 , pp. 4-5, 2015

[13] ES:262/2015, "Egyptian Standards for Steel Reinforcement." 